\title{
Private labels ain't bona fide! Perceived authenticity and willingness to pay a price premium for national brands over private labels
}

\section{Djavlonbek Kadirov}

To cite this article: Djavlonbek Kadirov (2015) Private labels ain't bona fide!

Perceived authenticity and willingness to pay a price premium for national brands over private labels, Journal of Marketing Management, 31:17-18, 1773-1798, DOI: 10.1080/0267257X.2015.1031265

To link to this article: http://dx.doi.org/10.1080/0267257X.2015.1031265

Published online: 11 Apr 2015.

Submit your article to this journal ¿

Џll Article views: 256

View related articles $₫$

View Crossmark data $\asymp$ 


\title{
Private labels ain't bona fide! Perceived authenticity and willingness to pay a price premium for national brands over private labels
}

\author{
Djavlonbek Kadirov, Business School, Eastern Institute of Technology, \\ Napier, New Zealand
}

\begin{abstract}
As private labels are consolidating their gains in national markets, a conventional recommendation to national brand manufacturers would most likely be to invest more in marketing in order to increase the perceived quality gap between national brands and private labels. It is assumed that the quality gap would boost consumer willingness to pay a price premium for national brands over private labels. Differing from this conventional approach, the current study focuses on the perceived authenticity gap between national brands and private labels, to explore whether and how this factor influences the effect of marketing and manufacturing variables on willingness to pay. This relationship is relevant in milieus where consumers might take brand authenticity rather than quality perceptions to guide their brand evaluations. The current study finds that the perceived authenticity gap mediates the effect of only some particular conventional marketing tools on willingness to pay. The study suggests that national brand managers should take the presence of private labels in the national markets as an opportunity to exploit the dynamics of authenticity evaluations, rather than as a threat.
\end{abstract}

Keywords perceived authenticity; quality gap; willingness to pay; private label; national brand; marketing mix effects

In this ever-changing society, the most powerful and enduring brands are built from the heart. They are real and sustainable. Their foundations are stronger because they are built with the strength of the human spirit, not an ad campaign. The companies that are lasting are those that are authentic.

- Howard Schultz, CEO of Starbucks, in Pour Your Heart Into It: How Starbucks Built a Company One Cup at a Time (Schultz \& Yang, 1997)

Private labels (PLs) are gradually gaining ground on national brands (NBs). Recent statistics attest to the growing scale of PL markets globally. The weighted global average of PL share has reached 16.5\% (Nielsen, 2014), whereas global PL sales in the fast-moving consumer goods (FMCG) sector increased by $24 \%$ over the period of 2007-2012 (Euromonitor, 2013). The recent Nielsen report (2014) indicates that from 2009 to 2013 PL shares grew in 16 European countries out of 21 surveyed, 
while moderate to strong growth was observed in the United States, China, Australia, and Latin American countries. India, despite its small retail concentration, registered an enormous 27\% increase in PL sales since 2012. PL penetration has reached $45 \%$ in Switzerland, while this indicator passed the $40 \%$ mark in the United Kingdom and Spain. The Nielsen Global PL Survey based on surveying 30,000 consumers in 60 countries also shows that consumer perceptions of PL value and quality have improved significantly (refer to Nielsen, 2014).

There has been a growing interest among researchers in studying factors that impact how much consumers would be willing to pay for NBs over PLs (Connor \& Peterson, 1992; Kumar \& Steenkamp, 2007; Livesey \& Lennon, 1978; Sethuraman, 2003; Sethuraman \& Cole, 1997, 1999; Skuras \& Vakrou, 2002; Soberman \& Parker, 2004, 2006; Steenkamp, Van Heerde, \& Geyskens, 2010). One of the key factors suggested is consumer perceptions of distinct quality levels attributed to NBs vis-à-vis PLs, conceptualised as a gap in perceived quality (Steenkamp et al., 2010). It has been demonstrated that the perceived quality gap not only drives willingness to pay for NBs over PLs (willingness to pay from here on), but also mediates the effect on this factor of a number of marketing and manufacturing factors (Steenkamp et al., 2010). However, the perceived quality gap may not be sustainable in the long term. It is known that PLs are continuously improving on quality (De Wulf, Odekerken-Schröder, Goedertier, \& Van Ossel, 2005). Anecdotal evidence suggests that there are cases when PL quality appears to match, or even significantly exceed, that of NBs. The Nielsen Global PL Survey shows that 71\% of consumers across the globe agree that PL quality has significantly improved over time, while 67\% of US consumers think that PL quality is as good as that of NB (Nielsen, 2014). Moreover, some empirical studies suggest that on average the quality advantage of NBs over PLs is very small (Apelbaum, Gerstner, \& Naik, 2003; Steenkamp et al., 2010). The study by Steenkamp et al. (2010) shows that willingness to pay tends to decrease as PLs attain maturity. This can be taken as an indication of growing retailer experience and expertise in competing on quality against NB manufacturers. Considering the current challenges that NBs are facing in maintaining a quality advantage over PLs, an important question arises as to what other opportunities (i.e. alternative factors or strategic options) exist that would guarantee consumers' sustained preference for NBs over PLs. In this study, we explore one of such alternative phenomena, brand authenticity, which represents a broader drive towards authenticity among consumers. Authenticity as a phenomenon is expected to become the cornerstone of marketing practice in the future (Beverland, 2009; Beverland \& Farrelly, 2010; Brown, Sherry, \& Kozinets, 2003; Kadirov, Varey, \& Wooliscroft, 2014; Peñaloza, 2000). However, authenticity is a complex notion that can take on different meanings in different contexts (Beverland \& Farrelly, 2010). Commonly used connotations of the concept in research include heritage, nostalgia, cultural symbolism, sincerity, craftsmanship, commitment to excellence, stylistic consistency, and moral virtue (Napoli, Dickinson, Beverland, \& Farrelly, 2014). In general, brand authenticity refers to the degree to which brands and their marketers are perceived to be real, sincere, and genuine (Beverland \& Farrelly, 2010; Napoli et al., 2014). Previous research has explored various aspects of the authenticity notion, including its attributes (Alexander, 2009; Beverland, 2005a), forms (Beverland, Lindgreen, \& Vink, 
2008), and cues (Grayson \& Martinec, 2004), as well as how personal goals influence authenticating strategies (Beverland \& Farrelly, 2010; Beverland, Farrelly, \& Quester, 2010), hyper-authenticity (Rose \& Wood, 2005), and authenticity commoditisation (Cohen, 1988; MacCannell, 1973). While the existing research on authenticity has predominantly been qualitative, there seems to be a dearth of quantitative research involving the concept (except for several attempts to quantify and operationalise the concept (Eggers, O'Dwyer, Kraus, Vallaster, \& Güldenberg, 2013; Kadirov, 2010; Napoli et al., 2014). To the best of our knowledge, there is no research in the field that investigates how PLs' or NBs' authenticity perceptions influence willingness to pay. Closing the latter research gap is important, especially in contexts where managers face a broad customer base whose general perceptions of quality may not significantly determine how much they are prepared to pay for NBs over PLs. In such specific cases, spending more on traditional marketing tools might not contribute to boosting willingness to pay, even though such a move may result in an increase in the perceived quality gap. It is of utmost importance that NB managers understand contexts in which only a few traditional marketing tools, subject to being skilfully managed, can positively influence brand authenticity, and thus lead to increased willingness to pay.

The purpose of the current research is to investigate the role of the perceived authenticity gap in shaping willingness to pay, and in mediating the effect of marketing and manufacturing factors on the same factor. To accomplish this, we first introduce and then discuss the general moderated-mediation framework of willingness-to-pay drivers, which includes the perceived authenticity gap as a mediating factor. Secondly, we then explain the methodological procedures that were used to collect data, operationalise and validate constructs, and estimate a hierarchical linear model. Lastly, we discuss the findings. In brief, we find that in our sample the perceived quality gap does not mediate the effect of marketing and manufacturing factors on willingness to pay, while the perceived authenticity gap is found to be a significant mediator of the effect. Furthermore, we find that an increase in the level of brand loyalty weakens the perceived authenticity gap's effect on willingness to pay. In addition, it is found that a number of marketing and manufacturing factors - namely product innovation, advertising, and PL production by NB manufacturers - have no significant effect on the perceived authenticity gap; while another set of factors, including distinctive packaging, price promotion, and the difficulty of producing the product, display a significant positive association with this factor under focus.

\section{Moderated-mediation framework}

\section{Original framework}

The original moderated-mediation framework proposed by Steenkamp et al. (2010) posits that the impact on willingness to pay of several marketing and manufacturing factors is mediated by the perceived quality gap: that is, the difference between PL and NB quality perceptions. The authors also suggest that the effect of the perceived quality gap on willingness to pay is moderated by two consumer-related factors: namely involvement (i.e. the extent to which 
consumers are involved in a product category) and the price-quality schema (i.e. the perception that price is an indicator of quality). The model also includes several marketing factors (e.g. consumer perceptions about product category innovation, distinctive packaging, advertising, price promotion), and the manufacturing determinants (e.g. consumer perceptions about PL production by NB manufacturers, the difficulty of producing the product). The empirical part of Steenkamp et al.'s study was in fact grandiose in scope - it has encompassed 23 countries, more than 22,000 respondents, and 63 product categories per country. The study found that the marketing and manufacturing factors included in the study did indeed determine the level of the perceived quality gap, which in turn influenced willingness to pay.

\section{The shift from quality to authenticity}

Following the principles set out by Steenkamp et al. (2010) in conceptualising the moderated-mediated framework, we modify and extend the application of the original model by replacing the perceived quality gap with the perceived authenticity gap as the main mediating factor. This move is motivated by the following rationale.

The concept of authenticity is becoming extremely relevant in the context of grocery shopping. The recent research shows that apart from iconic and luxury brands consumers do in fact search for authenticity even in the ordinary objects of consumption (Beverland, 2005a, 2009; Beverland \& Farrelly, 2010). It is known that authenticity perceptions are reified in relation to diverse products such as wines (Beverland, 2005b) and mass-marketed products (Beverland \& Farrelly, 2010). In addition, the research shows that consumers do in fact attribute authenticity to brands in general, and grocery brands in particular, although such attribution is largely contingent upon consumption contexts, consumer personalities, and life goals (Beverland, 2009; Beverland \& Farrelly, 2010).

Conceptually, brand authenticity perceptions refer to 'a subjective evaluation of genuineness ascribed to a brand by consumers' (Napoli et al., 2014, p. 1091). Beverland and Farrelly (2010) state that '...despite the multiplicity of terms and interpretations applied to authenticity, ultimately what is consistent across the literature is that authenticity encapsulates what is genuine, real, and/or true' ( $p$. 839). In contrast, product (brand) quality represents consumers' subjective judgement of a product's fitness for use (refer to American Society for Quality, http://asq.org/glossary/q.html). Authenticity appears to be a relatively broader, encompassing phenomenon, as the recent research shows that authenticity perceptions encompass quality perceptions, along with other factors such as sincerity and heritage (Napoli et al., 2014). In other words, authenticity can be defined as 'genuine quality' or 'sincerely executed quality'. These notions highlight a subtle perceptual distinction between excellence in performance attained through sincere concern for the customer (authenticity) and industrially produced superiority in performance that serves commercial motivations (quality) (Beverland, 2005b; Kadirov et al., 2014).

Focus on quality only is akin to what Podolny and Hill-Popper (2004) refer to as the 'hedonic value' context, in which the underlying assumption is that people are rational decision makers, and that they see objects as bundles of attributes. In contrast, the focus on authenticity echoes the 'transcendent value' settings, in 
which a person assesses the object (e.g. artwork), via developing an emotional link to its author's sincerity as well as his/her passion, aspirations, and devotion. In this context, the object's excellence would be perceived as a direct result of its maker's sincerity. Similarly, in the marketing context, authenticity perceptions depend on the extent to which consumers attribute genuineness to the makers of a brand (Beverland \& Farrelly, 2010; Beverland et al., 2008; Napoli et al., 2014). We maintain that consumers' evaluation of comparative monetary worth of NBs versus PLs is fundamentally different in the distinct value-assessment scenarios discussed by Podolny and Hill-Popper (2004). In general, the hedonic value is formed when consumers, while evaluating an exchange object, try to maintain social and emotional distance from the object, decompose this object into generalised attributes, and then rate the object according to these attributes. Under the pressure to choose, consumers apply hedonic evaluation to reduce the complexity of alternative exchange offerings, to make these offerings rationally comparable to each other (Podolny \& Hill-Popper, 2004). The consumer evaluations of quality of NBs versus PLs are likely to be driven by hedonic valuation motives. In contrast, under the transcendent conception of value, consumers reduce the social distance between themselves and the object, including its makers; immerse in the symbolic aura of an object through common identification and understanding; and develop a holistic evaluation of the object (Podolny \& Hill-Popper, 2004). In addition, Podolny and Hill-Popper (2004) argue that encouraging transcendent valuation characterises the approach of those marketers 'for whom authentic identity is a competitive advantage' (p. 96). Therefore, we maintain that authenticity sensitivities that set NBs apart from PLs in terms of monetary value are formed under the condition of transcendent valuation.

Furthermore, anecdotal evidence documented in the case of Snapple (Holt, 2004) and Dunlop Volley (Beverland, 2009) suggests that it is possible that in some circumstances consumers might be less inclined to use attribute-based quality perceptions to guide their brand preferences. Specifically, the cases of Snapple and Dunlop Volley demonstrate that some consumers appear to be indifferent to, if not euphoric about, the obvious quality shortcomings of the brands perceived to be the artefacts of sincerity. In turn, the marketers of these two brands did not attempt to cover up the brands' inferior quality. Instead, they deliberately exhibited a degree of pride in their own amateurism, and thus promoted a sincerity that differentiated them from other 'fake' offerings (Beverland, 2009). Such cases indicate that in some circumstances consumers might come to value authenticity more than quality. Hence, we maintain that:

Hypothesis 1: The perceived authenticity gap plays a mediating role between marketing factors and willingness to pay in the moderated-mediating framework.

\section{The effect of the perceived authenticity gap on willingness to pay}

The existing research shows how authenticity evaluations can become a powerful motive for consumption (Beverland \& Farrelly, 2010). In general, brands perceived to be authentic enjoy greater brand equity and charge greater price premiums (Beverland, 2005b, 2009). Specifically, consumer acceptance of luxury brands is 
directly proportional to the success of firms' brand authenticity-enhancing practices (Beverland, 2005b). In tourism research, a number of studies indicate that tourists exhibit an insatiable demand for authentic sites and artefacts (Cohen, 1988; MacCannell, 1999; Olsen, 2002). Furthermore, the research shows that consumers are willing to pay more for authentic food products, where authenticity is judged in terms of place of origin and being genuinely organic (Skuras \& Vakrou, 2002; Wier \& Calverley, 2002).

In the context of grocery shopping, a cohort of consumers of lower socioeconomic status might find themselves economically coerced into buying PLs, while PLs might not perfectly fit their actual needs. For example, consumers interested in cooking at home might feel discomfort when they are forced to make it work with a more basic-generic PL, when their specific recipes require original branded products. The richer assortment and variety offered by NBs could lead to the impression among consumers that NB producers are more sincere in providing what is needed. Hence, greater desire to purchase relevant brands might lead to greater willingness to pay a price premium. Moreover, those consumers who willingly purchase PLs self-identify as smart shoppers, and are driven by clichés such as 'I'm not stupid [to buy a national brand]' or 'manufacturer brands are rip-off' (Kumar \& Steenkamp, 2007). Although it is possible to interpret such consumer logic through the hedonic value frames as a quality-versus-price trade-off, it would be equally sensible to view it transcendentally: that is, consumers taking isolated instances of brand failure as the evidence of NB marketers' insincerity in their claims of commitment to consumer satisfaction and product quality. Brands epitomise marketer-customer relationships (Fournier, 1998), and hence the aforementioned clichés reflect consumers' summative boycott of $\mathrm{NBs}$ as they feel betrayed by brand manufacturers who are perceived to be insincere. In fact, a sincere attempt to satisfy consumer needs is recognised to be the true epitome of marketing (Gaski, 2013). A negative or neutral perceived authenticity gap may lead to lower levels of willingness to pay; while in contrast, a positive perceived authenticity gap might reflect consumer perception of NB manufacturers as being more genuine, satisfying real needs, and being sincerely committed to quality improvements. Consequently, a customer who feels that an NB is generally superior in terms of sincerity to a PL would place greater value on the former over the latter. All in all, the recent research shows that consumers' authenticity evaluations lead to greater purchase intention (Napoli et al., 2014), which leads us to believe that stronger intention to purchase will translate to greater willingness to pay.

Hypothesis 2: The perceived authenticity gap is positively associated with willingness to pay.

\section{The moderating effect of brand loyalty}

Previous research shows that brand loyalty generally has a negative association with PL demand and attitude (Ailawadi, Pauwels, \& Steenkamp, 2008; Garretson, Fisher, \& Burton, 2002). In general, brand-loyal consumers would be willing to pay more for NBs by default. In addition, consumers with the greater sense of brand loyalty might not face the difficulties of an NB versus PL 
choice to its full extent as it is known that brand-loyal consumers are not variety seekers (Garretson et al., 2002). Brand-loyal consumers are likely to feel less need for differential (i.e. NB vs. PL) authenticity evaluation as they tend to simply ignore PLs. Even if one is willing to accept that brand-loyal consumers form authenticity perceptions, in most cases such evaluations would not impact their willingness to pay. In other words, for brand-loyal consumers, higher perceived PL authenticity may not translate into lower willingness to pay for NBs.

Hypothesis 3a: Brand loyalty is positively associated with willingness to pay.

Hypothesis 3b: The greater the level of brand loyalty, the weaker the association between the perceived authenticity gap and willingness to pay.

\section{Marketing and manufacturing drivers of the perceived authenticity gap}

In contrast to the context of marketing factors' influence on the perceived quality gap (Steenkamp et al., 2010), the effect of marketing activities on the perceived authenticity gap is not unequivocal. Anecdotal evidence from the case of Snapple demonstrates that orthodox marketing practices not only weaken, but could also reverse, brandauthenticity perceptions (Holt, 2004). In particular, big marketing budgets and aggressive market strategies are not viewed positively by consumers, who tend to distrust corporate intentions of goodwill. Moreover, intensive marketing is thought to be detrimental to the so-called authentic 'mom-and-pop' businesses (Thompson, Rindfleisch, \& Arsel, 2006). Consumer perception of increased spending on conventional marketing practices might not go well with the seekers of authenticity as mass-marketing strategies are generally linked to the so-called Big Brother's malicious attempts to manipulate 'commoners' (Holt, 2002). Moreover, the excessive level of marketing might signal over-commercialisation that is directly antithetical to authenticity (Beverland, 2009; Holt, 2002; Kadirov et al., 2014). Existing research shows that authentic brand manufacturers interviewed by researchers insisted that they 'do not do marketing', thus striving to appear as resisting an 'evil' temptation to pursue orthodox marketing prescriptions (Beverland, 2009).

\section{Advertising perception}

As discussed previously, consumers might associate intensive marketing with the excessive profit focus that can be taken as the sign of inauthenticity (Holt, 2002). Since advertising is the most visible tool of marketing, and is seen as 'marketing' per se by some consumers, spending more on traditional advertising might not positively impact the perceived authenticity gap. In saying this, it should also be noted that not all advertising is necessarily ineffective in influencing authenticity. On the contrary, a recent qualitative inquiry finds that some carefully planned advertising is effective in reinforcing authenticity perceptions (Beverland et al., 2008). However, Beverland et al. (2008) explain that such advertising is indirect as it avoids both direct authenticity claims and unnecessary reference to marketing intensity. Paradoxically, advertising in this context might be effective when it does not lead to the consumer perception of increased advertising. However, if the real 
state of affairs is different to what is externally communicated (Beverland \& Luxton, 2005), then this is a potential case of inauthenticity due to the fact that consumers are growing increasingly inquisitive. They do their best to ascertain whether advertisers' externally projected values really represent what happens at 'backstage' (Holt, 2002). Therefore, by spending more on traditional advertising, even if it might be promoting brand authenticity, NBs are less likely to create an authenticity edge over PLs. In addition, it has been argued that consumers, specifically PL fans, are not easily influenced by advertising (Kumar \& Steenkamp, 2007). These consumers thoroughly distrust advertising and perceive it to be a tool of manipulation. Hence, by implication, NBs' claims, specifically those relating to quality, would be seen as non-genuine. Research shows that some consumers do not want to be fooled by direct quality claims and think that NBs are 'rip-off' (Kumar \& Steenkamp, 2007). Hence,

Hypothesis 4: Advertising perception will have a negative effect on the perceived authenticity gap.

\section{Product innovation perception}

Existing research shows that product innovation has a positive effect on the perceived quality gap (Steenkamp et al., 2010). In contrast, the factor's role in driving the perceived authenticity gap may not be as definite. There are several reasons to explain this. First, it should be noted that we are concerned with consumer perceptions of product category innovation. From this angle, what matters is the perceptual threshold of what is considered to be an innovation. Although authentic brand manufacturers might be fervent in introducing new and improved versions of their market offerings, this is mostly done in subtle increments. Moreover, changes are not promoted as radical, and we think that the major emphasis regarding innovation is on 'sticking to your own roots', 'stylistic consistency', and 'keeping traditions and founding spirit' (Beverland, 2009). Such authenticity clichés are likely to mask the extent of real product innovation. Indeed, an innovation that claims to go back to original roots is quite different in character and might not be perceived as innovation per se on the part of consumers. In other words, it is less likely that consumers will associate conventional innovation with authenticity. Furthermore, it is well documented that manufacturers often resort to historical themes in introducing the refined versions of authentic brands under the umbrella of retromarketing (Brown \& Sherry, 2003; Brown et al., 2003). Although it is an innovation, retromarketing is backward-oriented along a temporal continuum and might thus create confusion regarding the nature of innovation. The retrostrategy recreates and recycles past themes and meanings. Therefore, it is possible that consumers will not take the rebirth of an old idea as an innovation. Due to the reasons discussed above, we expect that

Hypothesis 5: In general, product innovation perception will have a negative effect on the perceived authenticity gap. 


\section{Distinctive packaging perception}

Consumers look for cues in packaging that convey authenticity meanings (Beverland, 2005b). Consumers' ability to differentiate between brands on the basis of packaging is expected to underpin the perceived authenticity gap. When we say 'distinctive' we do not refer to the physical intensity of differentials among stimuli (e.g. differences in size, shape, colour schemes, etc.). The perception of distinctiveness is a cultural phenomenon. Researchers argue that in general meaningfulness (i.e. sociocultural symbolism) underlies the extent to which brands are perceived to be different (Carpenter, Glazer, \& Nakamoto, 1994; Levy, 1959; McCracken, 1986). Hence, consumers could perceive a greater difference in packaging if these differences, apparent or subtle, are culturally relevant to day-to-day consumption rituals. Moreover, the distinctiveness of packaging is based on consumer perceptions (Steenkamp et al., 2010) and it is known that perceptions are interpretive. The instance of PLs copying NB packaging reduces, to a greater extent, absolute noticeable differences between packages. However, this incidence (i.e. PLs as copycats of NBs) in itself might play the role of a cue that reinforces NBs' cultural relevance. Even though an observable physical difference can be very small, a cultural distinction might be perceived to be significantly large. Although there is no doubt that the physical and design properties of packages can influence consumer judgements of distinctiveness, we argue that the ritualistic relevance of such differences is what that matters. Consequently, PLs, by copying NB packaging, do not only paradoxically increase (and/or reinforce) the distinctiveness of $\mathrm{NB}$ packaging, but also confer the authenticity of these NBs. When authenticity is in question, consumers detest obtrusiveness in branding, including labelling and packaging (Commuri, 2009). We think that subtle (less intense) but culturally distinctive cues are perhaps the real drivers of authenticity distinction.

\section{Hypothesis 6: Distinctive packaging perception will have a positive effect on the perceived authenticity gap.}

\section{Price promotion perception}

Price promotion is one of the conventional marketing tools, and its effect on the perceived authenticity gap could be equally positive or negative depending on the consumers' perspective. On the one hand, its influence on the perceived authenticity gap could be negative, as in the case of advertising perception. Consumers might see regular price promotions as a sign of excessively manipulative marketing. On the other hand, offering NBs frequently at special prices might go against consumer suspicions of excessive profiteering. Thus, if consumers perceive that NBs are doing their best in providing more price cuts while offering more value in terms of cultural relevance, then they might feel that the company is a sincere-real marketer that cares for its customers. Moreover, lower prices can be taken as the evidence of less commercial greed.

Moreover, it is quite possible that PLs in a specific category might make use of price promotions quite extensively. However, this might work against them under any scenario. When price promotions are perceived to be 'sacrifices', consumers' established expectation of low prices for PLs might hinder them viewing PL price 
promotions as sincere. When price promotion is seen as a manipulative marketing tactic, more price promotion by PLs could end up boosting the authenticity evaluations for NBs. Hence,

Hypothesis 7: Consumer perception of increased price promotion might lead to a greater perceived authenticity gap.

\section{Manufacturing drivers}

Accepting Steenkamp et al.'s (2010) proposition, we consider the effect of two manufacturing drivers, namely the consumer perception of PL production by NB manufacturers (PL production), and the perception of product manufacturing being difficult (the difficulty of production). As it is known that major NB manufacturers are involved in PL production, and consumers are more or less aware of this (Kumar \& Steenkamp, 2007; Steenkamp et al., 2010), the increased perception of PLs being made by NB manufacturers might negatively influence NBs' perceived authenticity. Moreover, PLs might also benefit from the perception of increased quality in this case (Steenkamp et al., 2010). Hence, such perceptions might contribute to slightly increased levels of PL authenticity as PL sponsors would be seen as people who are sincerely dedicated to quality of produce. Pams (one of the PL labels in New Zealand) has long been advertising its owners' 'passion for food' (www.pams.co.nz). Such a tendency would lead to a decreasing gap between authenticity perceptions of NBs versus PLs.

The difficulty of production has a positive effect on quality (Steenkamp et al., 2010). By analogy, we argue that if consumers perceive production processes to be complex and skill-demanding, then they might attribute greater passion and sincere dedication to the makers of NBs. Hence,

Hypothesis 8a: PL production has a negative effect on the perceived authenticity gap.

Hypothesis 8b: The difficulty of production has a positive effect on the perceived authenticity gap.

\section{Method}

\section{Conceptual framework}

Figure 1 demonstrates the general conceptual framework that we use for our modelling purposes. Although the framework has a degree of similarity to the model proposed by Steenkamp et al. (2010), the quality/authenticity replacement in the framework implies a notable conceptual shift. The following differences must be noted: (1) the framework we propose marks a general shift from the tradition of seeing brands as 'objects' (to be acquired in the immediate shopping context) towards thinking about brands as relationships (Fournier, 1998); (2) in the former tradition, apparent quality differences and related moderators (e.g. involvement, price quality perceptions) take centre stage, whereas the latter logic requires focus on distinct phenomena that arise within the milieu of consumermarketer relationships (e.g. authenticity, brand loyalty); (3) our model hinges on 
Figure 1 Conceptual framework.

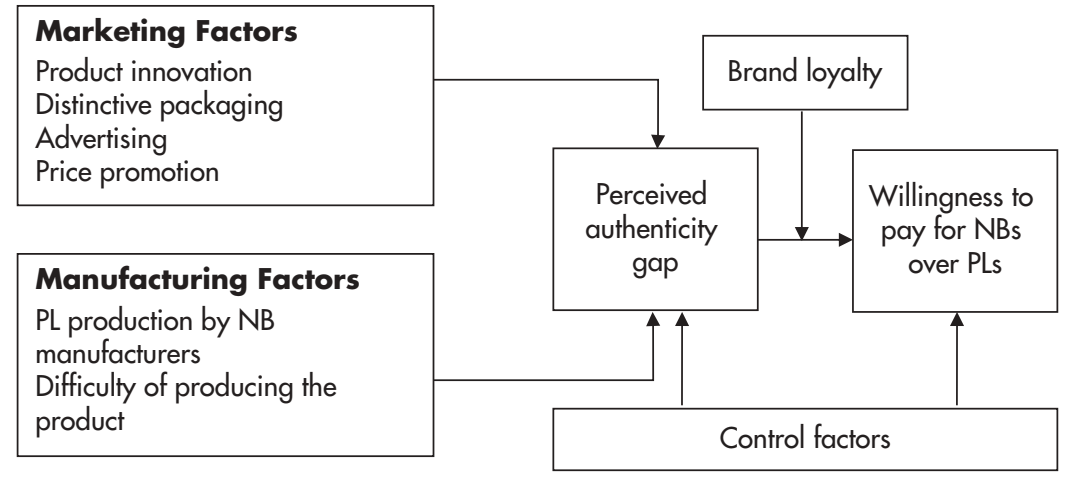

the premise that consumers evaluate brands transcendentally, whereas Steenkamp et al. presume consumers to be hedonistic evaluators due to their main emphasis on quality; and (4) on the technical side, the model in the current study is adapted to the context of a single country, whereas Steenkamp et al.'s framework is international and is set to estimate inter-country differences.

\section{Data collection and construct operationalisation}

The data used in this study was collected from a number of cities and townships located in the central and eastern regions of New Zealand. The study participants were sampled in such a way as to ensure that a wider representation of different socio-economic layers was attained. At the outset, we ran a pilot test with the initial draft of the questionnaire on a small sample of respondents. After making appropriate modifications, the finalised questionnaire was used by trained interviewers to approach respondents in malls, shopping centres, campuses, festivities, and larger community and family gatherings. To avoid potential misunderstanding and reduce inability to complete the questionnaire, the interviewers were instructed to provide detailed explanation of questions to interviewees as they deemed it necessary. No incentives were offered to the respondents for their participation.

Twenty different product categories from food, beverage, and household care subgroups were included in the study. Each respondent was randomly assigned to evaluate two product categories out of the list available. In addition, the respondents provided information on their shopping behaviour and sociodemographics. The respondents were initially screened to ascertain that they were involved in grocery shopping on a routine basis and had prior experience of making purchases in a selected product category. As only two supermarket chains are dominant in New Zealand - namely Progressive and Foodstuffs - the questionnaire included examples of NBs and PLs in the selected categories in these two chains to help the respondents visualise the scope of the study. In total, 661 respondents were interviewed, and this resulted in 1201 usable observations. The number of observations per product category averaged 60, while this number ranged from 39 to 99 for individual categories. 
Table 1 reports the constructs, their operationalisation, sources, and reliability indices. We use Steenkamp et al.'s (2010) approach to operationalising the main constructs. Willingness to pay is measured as a 'percentage-price-premium' index (Palmatier, Scheer, \& Steenkamp, 2007; Steenkamp et al., 2010). The metrics of marketing and manufacturing variables are seven-point Likert scales that have been adapted from Steenkamp et al. (2010). The perceived quality gap is calculated by subtracting PL quality scores from NB quality scores (Steenkamp et al., 2010). Similarly, the perceived authenticity gap is set as the difference between NB and PL authenticity scores. The latter two indices range from -10 (e.g. PLs are more authentic than NBs) to +10 (e.g. NBs are more authentic than PLs). In addition, several control variables have been included in the study. These comprise the following: (1) sociodemographic factors: namely age, gender, income, education, household size, family status, social class; (2) factors related to shopping behaviour, such as number of store visits per week, grocery spend per week per person, and PL proneness; (3) two dummy variables for product categories: household care and beverages, while food is set as a baseline category; and (4) three dummy variables for the largest supermarket brands.

\section{Validation and estimation}

Confirmatory factor analysis is used to evaluate the convergent and discriminant validity of the constructs (i.e. perceived authenticity of PLs, perceived authenticity of NBs, product innovation perception, distinctive packaging perception, advertising perception, price promotion perception, difficulty of production, PL production, and brand loyalty). The individual-level observations are pooled into a measurement structural equation model. As is the case with large samples, the chi-squared value $\left(\chi^{2}(136)=402.59, p<.001\right)$ is highly significant. The Hoelter measure $($ HOELTER $=490)$ suggests that this significance is indeed due to the largeness of the sample. Hence, the $\chi^{2}$ measure is unreliable as a measure of model fit. The other model fit indicators are found to be satisfactory $(\mathrm{CMIN} / \mathrm{DF}=2.96$, CFI $=.97$, TLI $=.95$, RMSEA $=.04$, and PCLOSE $=1)$. The factor loadings of all indicators on their corresponding latent variables are significant $(p<.01)$ and exceed 0.6 (except the reversed item of the brand-loyalty construct). The correlation matrix is satisfactory as all correlations between the constructs are significantly below 1 . Based on the analysis of the results given above, we conclude that the evidence lends substantial weight to the acceptable convergent and discriminant validity of the constructs. Moreover, these findings are consistent with Steenkamp et al.'s (2010) conclusion that the marketing and manufacturing constructs developed in their study exhibit the satisfactory levels of validity.

To estimate the hypothesised effects, we developed a three-level hierarchical linear model (Raudenbush \& Bryk, 2002). The first-level model comprises all individual-level observations, while the second-level model involves product categories. The third level is defined as a store patronage group level. To create store patronage groups, we classify individuals according to their supermarket patronage behaviour. Supermarket patronage is measured via a (self-reported) percentage of weekly shopping expenditure at a particular store. We create store patronage groups by combining weekly expenditure percentages for the three dominant supermarket brands (Pak'nSave, New World, and Countdown). The three out of a conceptualised six store patronage groups 
Table 1 Operationalisation of constructs.

\begin{tabular}{|c|c|c|c|}
\hline Construct & Operationalisation & Source & Cronbach \\
\hline $\begin{array}{l}\text { Willingness to pay for } \\
\text { NBs over PLs }\end{array}$ & $\begin{array}{l}\text { In the category } X \text {, how much more are } \\
\text { you willing to pay for a brand compared } \\
\text { to a shop's own label? } \\
0 \% \text { (nothing); } 10 \% \text { more; } 20 \% \text { more; } 30 \% \\
\text { more; } 40 \% \text { more; } 50 \% \text { more; } 75 \% \\
\text { more; } 100 \% \text { more (twice as much); } \\
\text { more than } 100 \% \text { (more than twice as } \\
\text { much) }\end{array}$ & $\begin{array}{l}\text { Steenkamp et al. } \\
\text { (2010) }\end{array}$ & \\
\hline $\begin{array}{l}\text { Perceived authenticity } \\
\text { gap }\end{array}$ & 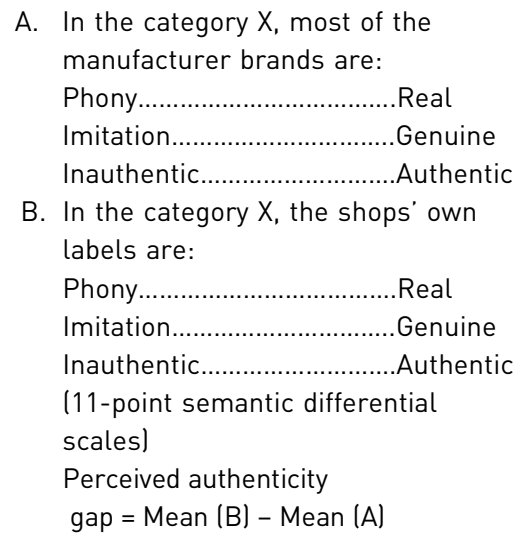 & $\begin{array}{l}\text { Author's own } \\
\text { development }\end{array}$ & $\begin{array}{l}\text { A } 0.90 \\
\text { B } 0.92\end{array}$ \\
\hline Perceived quality gap & $\begin{array}{l}\text { A. In the category } X \text {, shops' own labels } \\
\text { are of: } \\
\text { Inferior quality.....................Superior } \\
\text { quality } \\
\text { B. In the category X, manufacturer } \\
\text { brands are of: } \\
\text { Inferior quality...................Superior } \\
\text { quality } \\
\text { (11-point semantic differential } \\
\text { scales) } \\
\text { Perceived quality gap = B - A }\end{array}$ & $\begin{array}{l}\text { Adapted from } \\
\text { Erdem, Swait, and } \\
\text { Valenzuela (2006) }\end{array}$ & \\
\hline Brand loyalty & $\begin{array}{l}\text { - Once I choose a brand, I don't like to } \\
\text { switch } \\
\text { - I prefer the brand I always buy instead } \\
\text { of trying another one that I'm not sure } \\
\text { about } \\
\text { - I see myself as a brand-loyal person } \\
\text { - If my preferred brand is not in the } \\
\text { supermarket, I can easily choose } \\
\text { another brand (r) }\end{array}$ & $\begin{array}{l}\text { Ailawadi et al. } \\
\text { (2008) }\end{array}$ & 0.62 \\
\hline \multicolumn{4}{|c|}{ Marketing and manufacturing factors } \\
\hline Product innovation & $\begin{array}{l}\text { - In the category } X, \text { new products are } \\
\text { frequently introduced } \\
\text { - There are many new product } \\
\text { introductions in category } X\end{array}$ & $\begin{array}{l}\text { Steenkamp et al. } \\
\text { (2010) }\end{array}$ & 0.77 \\
\hline
\end{tabular}


Table 1 (Continued).

\begin{tabular}{|c|c|c|c|}
\hline Construct & Operationalisation & Source & Cronbach \\
\hline Distinctive packaging & $\begin{array}{l}\text { - On the shelf of category } X, I \text { cannot tell } \\
\text { a shop's own label from a brand as } \\
\text { packages are very similar (r) } \\
\text { - In the category } X \text {, shops' own labels } \\
\text { and brands look very similar ( } r \text { ) }\end{array}$ & $\begin{array}{l}\text { Steenkamp et al. } \\
\text { (2010) }\end{array}$ & 0.66 \\
\hline Advertising & $\begin{array}{l}\text { - Brands in the category } X \text { are heavily } \\
\text { advertised in magazines, on radio, or } \\
\text { on TV } \\
\text { - There is a lot of advertising for } \\
\text { brands in the category } X\end{array}$ & $\begin{array}{l}\text { Yoo, Donthu, and } \\
\text { Lee (2000) }\end{array}$ & 0.77 \\
\hline Price promotion & $\begin{array}{l}\text { - There is always a special offer in } \\
\text { category } X \\
\text { - It is easy to find a special offer in } \\
\text { category } X\end{array}$ & Yoo et al. (2000) & 0.73 \\
\hline $\begin{array}{l}\text { PL production by NB } \\
\text { manufacturers }\end{array}$ & $\begin{array}{l}\text { - In the category X, shop's own labels } \\
\text { are produced by brand manufacturers }\end{array}$ & $\begin{array}{l}\text { Steenkamp et al. } \\
\text { (2010) }\end{array}$ & \\
\hline $\begin{array}{l}\text { Difficulty of producing } \\
\text { the product }\end{array}$ & $\begin{array}{l}\text { - In the category } X, \text { making good-quality } \\
\text { products is difficult }\end{array}$ & $\begin{array}{l}\text { Steenkamp et al. } \\
\text { (2010) }\end{array}$ & \\
\hline \multicolumn{4}{|l|}{ Demographics } \\
\hline PL proneness & $\begin{array}{l}\text { Generally l'm someone who likes buying } \\
\text { shops' own labels }\end{array}$ & & \\
\hline Household size & $\begin{array}{l}\text { What is the size of your household? } \\
\text { (Please count all persons ladults as } \\
\text { well as children) who live in your } \\
\text { household at least } 4 \text { days per week, } \\
\text { including yourself) }\end{array}$ & & \\
\hline Education & $\begin{array}{l}\text { Which of these best describes your } \\
\text { highest level of education? } \\
\text { No formal education; primary school or } \\
\text { less; some high school; high school } \\
\text { graduate; some college or polytechnic } \\
\text { education; college or polytechnic } \\
\text { graduate; some university education; } \\
\text { university graduate (undergraduate); } \\
\text { university graduate (postgraduate) }\end{array}$ & & \\
\hline Social class & $\begin{array}{l}\text { If people in our society are divided into } \\
\text { upper, upper-middle, middle, lower- } \\
\text { middle, working, and lower classes, } \\
\text { which class do you think you belong to? } \\
\text { Underclass; lower-working class; upper- } \\
\text { working class; lower-middle class; } \\
\text { middle-middle class; upper-middle } \\
\text { class; upper class }\end{array}$ & & \\
\hline Family status & $\begin{array}{l}\text { Dummy variable: } 1 \text { - single; } 0 \text { - not } \\
\text { single }\end{array}$ & & \\
\hline
\end{tabular}

There is always a special offer in

It is easy to find a special offer in

In the category $X$, shop's own labels

ifficulty of producing

In the category $x$, making good-quality

teenkamp et al.

the produr

products is difficult 
represent individuals who are loyal to one of the above-mentioned supermarkets: that is, who spend most of their weekly grocery shopping expenditure at that particular store. The other three store patronage groups have been created to represent those consumers who reported equal weekly spend percentages for two supermarkets at a time. Thus, the model included $i=1, \ldots, n_{j k}$ individual observations at the first level that were nested within $j=1, \ldots, J_{k}$ product categories (the second level) that in turn were nested within each of $k=1, \ldots, K$ store patronage groups. In simple words, the level 1 model comprised the relationship of the conceptualised constructs at an individual level; the level 2 model captured the influence of category-level factors, namely the beverages and household-care category dummies; while the level 3 model took into account the effects of store patronage-level factors (i.e. three dummy variables for supermarkets).

We centre the level 1 continuous variables within the categories and the store patronage groups (Raudenbush \& Bryk, 2002). Centring does not apply to the level 2 and level 3 dummy variables. The constructs of interest are specified as random effects, while control variables and the level 2 and 3 variables are constrained to be constant across the store patronage groups. At level 1, the hierarchical linear model is set to have a random error term, uijk $\sim N\left(0, \sigma^{2}\right)$. The level 2 model has a vector of error terms (rpjk) that is distributed as multivariate normal, where each unit has a zero mean and variance defined by $\operatorname{var}(r p j k)=\tau \pi p p$ and $\left.\operatorname{cov}\left(r p j k, r p^{\prime} j k\right)=\tau \pi p, p^{\prime}\right)$. The dispersion matrix $T \pi$ with a maximum dimension of $(P+1) \times(P+1)$ contains the level 2 variance and covariance components. Also, we assume the vector of the level 3 error terms (upqk) to be distributed as multivariate normal with zero mean and the dispersion matrix $T \beta$, the dimension of which is $\sum_{p=0}^{p}\left(Q_{p}+1\right) \times \sum_{p=0}^{p}\left(Q_{p}+1\right)$.

\section{Findings}

\section{Descriptive findings}

The average level of willingness to pay for the whole sample is 26.35. For comparison, willingness-to-pay levels reported by Steenkamp et al. (2010) are 12.79 and 10.56 on average for PL development and PL maturity countries, respectively. Considering that New Zealand is more likely to be classified as a PL maturity country, this number appears to be relatively high. However, the high willingness-to-pay score is not unwarranted. As it is known that willingness to pay is negatively correlated with PL share (Steenkamp et al., 2010) and that PL share in New Zealand is estimated to be in the range of 13-13.5\% (Nielsen, 2014), which is moderately low (compared to Switzerland's 45\% and the United Kingdom's 41\%), we deem the average level of willingness to pay to be plausible. Moreover, we find that the reported willingness-to-pay scores are greater for those consumers who patronise the supermarket brand New World $(t=3.45$ (1197), $p<.001)$. This fact adds more credibility to the findings as New World is known to be more NBoriented and offers services that are tailored for higher-end grocery shopping. New Zealanders seem to place greater value on NBs as $87.4 \%$ expressed their willingness to pay at least $10 \%$ more for NBs over PLs, while $21.2 \%$ of the sample expressed their readiness to pay $50 \%$ or more for NBs over PLs. 
Table 2 Comparative descriptive statistics.

\begin{tabular}{|c|c|c|c|}
\hline Variable statistics & $\begin{array}{c}\text { Perceived } \\
\text { authenticity gap } \\
\text { (the current study) }\end{array}$ & $\begin{array}{l}\text { Perceived quality gap } \\
\text { (the current study) }\end{array}$ & $\begin{array}{l}\text { Perceived quality } \\
\text { gap (Steenkamp } \\
\text { et al., 2010) }\end{array}$ \\
\hline $\begin{array}{l}X>0, \text { National brands } \\
\text { advantage over } \\
\text { private labels }\end{array}$ & $68.9 \%$ & $72.8 \%$ & $39 \%$ \\
\hline$X=0$, No difference & $20.2 \%$ & $18.1 \%$ & $43 \%$ \\
\hline $\begin{array}{l}X<0 \text {, Private labels } \\
\text { advantage over NBs }\end{array}$ & $10.9 \%$ & $9.1 \%$ & $18 \%$ \\
\hline Mean & 2.12 & 3.09 & $0.85^{*}$ \\
\hline $\begin{array}{l}\text { Coefficient of } \\
\text { variation }\end{array}$ & 1.32 & 1.09 & 3.32 \\
\hline
\end{tabular}

Table 2 exhibits the descriptive statistics of the perceived authenticity gap versus the perceived quality gap, as well as those of the perceived quality gap from Steenkamp et al.'s (2010) study for comparison. In the current sample, the perceived authenticity gap appears to be more heterogeneous than the perceived quality gap. In comparison to the perceived quality gap, the perceived authenticity gap's mean level is significantly lower $(t=13.65(1199), p<.001)$ and its dispersion is greater. Both the perceived authenticity gap and the perceived quality gap show significantly less heterogeneity in comparison to the perceived quality gap reported by Steenkamp et al. (2010). This fact is also supported by the reported percentages of consumers who think that NBs have authenticity and quality advantage over PLs. In Steenkamp et al.'s sample, a majority of consumers (61\%) either saw no quality difference between NBs and PLs, or thought that PLs are better than NBs. In the current study, this pattern is reversed. More than two-thirds of consumers gave both authenticity and quality advantage to NBs, while less than one-third saw no difference or gave advantage to PLs.

\section{Mediating effects of perceived authenticity versus perceived quality}

Following Steenkamp et al.'s (2010) approach, we apply Baron and Kenny's (1986) procedure to test whether the perceived authenticity gap (or alternatively the perceived quality gap) mediates the effect of marketing and manufacturing variables on willingness to pay. We recognise that there has been a significant debate in the field on the preferability of the procedure over available alternative options (Preacher \& Hayes, 2004; Zhao, Lynch, \& Chen, 2010). Specifically, the advice is that test results must be thoroughly scrutinised when a mediator lacks discriminant validity or if mediation signs are found to be different to the researcher's expectations (Zhao et al. 2010). As this is not the case with our study, we decide to continue with Baron and Kenny's procedure. It must also be noted that Zhao et al. (2010) admit that the Sobel test associated with the current procedure is only slightly less powerful than alternative bootstrap-based techniques.

To test for a possible mediating effect by the perceived quality gap, initially the perceived quality gap and the two suggested moderators (involvement and price 
quality schema) are introduced into the model. The results of the analysis are reported in Table 3. As no significant association between the perceived quality gap and willingness to pay is found, we conclude that in our sample there is not enough evidence to suggest that the perceived quality gap mediates the effect of the focal variables on willingness to pay.

Table 3 Perceived quality gap: no mediation.

\begin{tabular}{|c|c|c|c|c|}
\hline & \multicolumn{2}{|c|}{$\begin{array}{c}\text { Total effect on } \\
\text { willingness to pay }\end{array}$} & \multicolumn{2}{|c|}{$\begin{array}{l}\text { Perceived quality } \\
\text { gap - direct effect }\end{array}$} \\
\hline & Coefficient & $t$-Value & Coefficient & $t$-Value \\
\hline Intercept & 29.22 & $9.74^{* * *}$ & 28.81 & $9.85^{* * *}$ \\
\hline Product innovation & -0.37 & -0.35 & -0.67 & -0.70 \\
\hline Distinctive packaging & 1.57 & $2.07 * *$ & 0.03 & 0.05 \\
\hline Advertising & 0.36 & 0.38 & 0.01 & 0.01 \\
\hline Price promotion & 2.72 & $2.71 * * *$ & 2.03 & $2.08^{* *}$ \\
\hline PL production by NB manufacturers & -1.19 & -1.16 & -1.13 & -1.23 \\
\hline Difficulty of producing the product & 1.63 & $2.87^{* * *}$ & 0.82 & 1.46 \\
\hline Perceived quality gap & & & -1.38 & -1.49 \\
\hline Involvement & & & 0.68 & 0.92 \\
\hline Perceived quality gap involvement & & & 0.02 & 0.13 \\
\hline Price quality schema & & & 1.64 & $2.06^{* *}$ \\
\hline $\begin{array}{l}\text { Perceived quality gap price quality } \\
\text { schema }\end{array}$ & & & 0.59 & $3.45^{* * *}$ \\
\hline \multicolumn{5}{|l|}{ Control variables } \\
\hline Household size & 0.61 & 1.03 & 0.77 & 1.35 \\
\hline Gender & -2.06 & -1.35 & -2.39 & $-1.63^{*}$ \\
\hline Age & -0.14 & $-2.25^{* *}$ & -0.08 & -1.40 \\
\hline Education & 0.63 & 1.47 & 0.42 & 1.02 \\
\hline Social class & -0.97 & $-1.84^{*}$ & -0.88 & $-1.73^{*}$ \\
\hline Income & 0.00 & 1.46 & 0.00 & 1.28 \\
\hline Family status & -0.54 & -0.30 & -0.41 & -0.24 \\
\hline Store visits & 0.01 & 0.01 & -0.16 & -0.25 \\
\hline Grocery spending per person & 0.01 & 0.33 & 0.01 & 0.72 \\
\hline PL proneness & -5.34 & $-7.61^{* * *}$ & -3.47 & $-4.95^{* * *}$ \\
\hline Category dummy: household care & -0.37 & -0.10 & -0.21 & -0.06 \\
\hline Category dummy: beverages & 5.27 & $2.10 * *$ & 5.98 & $2.42^{* *}$ \\
\hline Supermarket 1 dummy & -1.61 & -0.51 & -1.20 & -0.38 \\
\hline Supermarket 2 dummy & -6.71 & -1.90 & -6.00 & -1.72 \\
\hline Supermarket 3 dummy & 1.81 & 0.51 & 2.32 & 0.67 \\
\hline $2 \mathrm{LL}$ & $10,777.26$ & & $10,679.13$ & \\
\hline Parameters & 52 & & 57 & \\
\hline AIC & $10,881.26$ & & $10,793.13$ & \\
\hline $\mathrm{BIC}$ & $11,144.32$ & & $11,081.48$ & \\
\hline
\end{tabular}

Note: ${ }^{* * *} p<0.01 ;{ }^{* *} p<0.05 ;{ }^{*} p<0.10$. 
Table 4 shows that the perceived authenticity gap mediates the effect of the marketing and manufacturing variables on willingness to pay. When the perceived authenticity gap and brand loyalty (a moderating variable) are entered into the model, the effects of the main variables are considerably reduced (all Sobel statistics

Table 4 Perceived authenticity gap: mediation effect.

\begin{tabular}{|c|c|c|c|c|c|}
\hline & \multicolumn{2}{|c|}{$\begin{array}{l}\text { Total effect on } \\
\text { Willingness to pay }\end{array}$} & \multicolumn{2}{|c|}{$\begin{array}{c}\text { Perceived } \\
\text { authenticity gap - } \\
\text { direct effect }\end{array}$} & \multirow{2}{*}{$\begin{array}{c}\text { Perceived } \\
\text { authenticity gap } \\
\text { - indirect effect } \\
\% \text { mediation }\end{array}$} \\
\hline & Coefficient & $t$-Value & Coefficient & $t$-Value & \\
\hline Intercept & 29.22 & $9.74^{* * *}$ & 29.16 & $9.91 * * *$ & \\
\hline Product innovation & -0.37 & -0.35 & -0.17 & -0.17 & 54.20 \\
\hline Distinctive packaging & 1.56 & $2.07 * *$ & 0.62 & 0.81 & 60.30 \\
\hline Advertising & 0.35 & 0.38 & 0.01 & 0.01 & 96.00 \\
\hline Price promotion & 2.72 & $2.71^{* * *}$ & 2.29 & $2.43^{* *}$ & 18.80 \\
\hline $\begin{array}{l}\text { PL production by NB } \\
\text { manufacturers }\end{array}$ & -1.19 & -1.16 & -0.96 & -1.00 & 1.90 \\
\hline $\begin{array}{l}\text { Difficulty of producing } \\
\text { the product }\end{array}$ & 1.63 & $2.87^{* * *}$ & 1.43 & $2.53^{* *}$ & 12.40 \\
\hline $\begin{array}{l}\text { Perceived authenticity } \\
\text { gap }\end{array}$ & & & 4.45 & $3.65^{* * *}$ & \\
\hline Brand loyalty & & & 3.27 & $2.69 * * *$ & \\
\hline $\begin{array}{l}\text { Perceived authenticity } \\
\text { gap brand loyalty }\end{array}$ & & & -0.53 & $-1.87^{*}$ & \\
\hline \multicolumn{6}{|l|}{ Control variables } \\
\hline Household size & 0.61 & 1.03 & 0.79 & 1.38 & \\
\hline Gender & -2.06 & -1.35 & -2.50 & $-1.69 *$ & \\
\hline Age & -0.14 & $-2.25^{* *}$ & -0.11 & $-1.77^{*}$ & \\
\hline Education & 0.63 & 1.47 & 0.41 & 0.99 & \\
\hline Social class & -0.97 & $-1.84^{*}$ & -0.83 & $-1.61 *$ & \\
\hline Income & 0.00 & 1.46 & 0.00 & 1.31 & \\
\hline Family status & -0.54 & -0.30 & -0.21 & -0.12 & \\
\hline Store visits & 0.01 & 0.01 & -0.05 & -0.09 & \\
\hline $\begin{array}{l}\text { Grocery spending per } \\
\text { person }\end{array}$ & 0.01 & 0.33 & 0.01 & 0.67 & \\
\hline PL proneness & -5.34 & $-7.61 * * *$ & -4.19 & $-6.01 * * *$ & \\
\hline Household care & -0.37 & -0.11 & 0.37 & 0.11 & \\
\hline Beverages & 5.27 & $2.10^{* *}$ & 5.38 & $2.15^{* *}$ & \\
\hline Supermarket 1 dummy & -1.61 & -0.51 & -1.33 & -0.42 & \\
\hline Supermarket 2 dummy & -6.71 & -1.90 & -6.46 & -1.85 & \\
\hline Supermarket 3 dummy & 1.81 & 0.51 & 1.87 & 0.53 & \\
\hline $2 \mathrm{LL}$ & $10,777.26$ & & $10,711.08$ & & \\
\hline Parameters & 52 & & 55 & & \\
\hline $\mathrm{AIC}$ & $10,881.26$ & & $10,821.08$ & & \\
\hline $\mathrm{BIC}$ & $11,144.32$ & & $11,099.31$ & & \\
\hline
\end{tabular}

Note: ${ }^{* * *} p<0.01 ;{ }^{* *} p<0.05 ;{ }^{*} p<0.10$. 
are significant at $p<.10$ ). The extent of reduction can be measured via the relative ratio of the indirect effect of an independent variable to its total effect (Steenkamp et al., 2010). For significant effects, this ratio ranged from $12.4 \%$ to $60.3 \%$. The average magnitude of the ratio for all main variables was $40.6 \%$. In addition, as a result of the perceived authenticity gap inclusion, the model fit has improved significantly $\left(\chi^{2}(3)=66.41, p<.001\right)$. The first hypothesis is supported: in our sample, the perceived authenticity gap does indeed mediate the effect of marketing factors on willingness to pay.

\section{Willingness to pay, perceived authenticity gap, and its drivers}

Table 5 reports the results of overall model estimation. In this final stage of the analysis, willingness to pay is regressed on the perceived authenticity gap and brand loyalty (a moderating factor), and then the perceived authenticity gap is separately regressed on the marketing and manufacturing variables. We find a strong positive relationship between the perceived authenticity gap and willingness to pay $(\beta=4.71$, $p<.01$ ) which lends support to Hypothesis 2. As expected, brand loyalty has a negative moderating effect on the perceived authenticity gap-willingness to pay relationship $(\beta=-.51, p<.10)$, while the main effect is positive $(\beta=3.15$, $p<.01)$. Based on this, we conclude that there is enough evidence to accept Hypotheses $3 \mathrm{a}$ and $3 \mathrm{~b}$.

Further, the three marketing and manufacturing factors (namely product innovation, advertising, and PL production) that were expected to have a negative association with the perceived authenticity gap were found to have no significant impact on this factor. Hence, these findings led us to reject Hypotheses 4, 5, and $8 \mathrm{a}$. The effects on the perceived authenticity gap of distinctive packaging $(\beta=.42, p<.01)$, price promotion $(\beta=.16, p<.10)$, and the difficulty of producing the product $(\beta=.11, p<.05)$ are significantly positive. In general, these results confirm our expectations expressed through Hypotheses 6, 7, and 8b (Table 6).

\section{Discussion and managerial implications}

In the FMCG context, the default assumption is that brands are represented by 'things' (objects) on offer displayed in supermarket shelves; hence the essentialist assumption that consumers would be willing to pay for brands' apparent differential attributes (i.e. the quality gap). Both researchers and practitioners tend to forget that consumers could also assess a brand or label as a hallmark of customer-marketer relationships (Fournier, 1998), the context in which authenticity takes a centre stage. This investigation finds that the majority of consumers in our sample tend to let their authenticity evaluations determine how much they would be willing to pay for NBs versus PLs, while transcending the physicality of the objects to holistically assess the passion, commitment, and sincerity of the makers (Holt, 2004; Woodall, 2012). This finding can also be interpreted as consumers' attempts to eliminate the centrality of the objects (and accompanying efforts related to rational deliberations) from consumer-marketer relationships as the recent research shows that consumers strive to make household items 'invisible' in their lives (Coupland, 2005). For these 
Table 5 Overall model estimation results.

\begin{tabular}{|c|c|c|c|c|}
\hline & \multicolumn{2}{|c|}{$\begin{array}{c}\text { Perceived } \\
\text { authenticity gap }\end{array}$} & \multicolumn{2}{|c|}{ Willingness to pay } \\
\hline & Coefficient & $t$-Value & Coefficient & $t$-Value \\
\hline Intercept & 1.13 & $3.57^{*}$ & 29.71 & $9.52 * * *$ \\
\hline Product innovation & -0.05 & -0.61 & & \\
\hline Distinctive packaging & 0.42 & $5.84^{* * *}$ & & \\
\hline Advertising & 0.12 & 1.60 & & \\
\hline Price promotion & 0.16 & $1.87^{*}$ & & \\
\hline PL production by NB manufacturers & -0.09 & -1.06 & & \\
\hline Difficulty of producing the product & 0.11 & $1.98^{* *}$ & & \\
\hline Perceived authenticity gap & & & 4.71 & $3.80^{* * *}$ \\
\hline Brand loyalty & & & 3.15 & $2.49 * * *$ \\
\hline Perceived authenticity gap brand loyalty & & & -0.50 & $-1.73^{*}$ \\
\hline \multicolumn{5}{|l|}{ Control variables } \\
\hline Household size & -0.08 & -1.38 & 0.85 & 1.40 \\
\hline Gender & 0.18 & 1.12 & -1.84 & -1.18 \\
\hline Age & -0.01 & $-2.22^{* *}$ & -0.12 & $-1.81 *$ \\
\hline Education & 0.11 & $2.51 * * *$ & 0.22 & 0.51 \\
\hline Social class & -0.05 & -0.98 & -0.84 & -1.56 \\
\hline Income & 0.01 & $1.79 *$ & 0.00 & 1.20 \\
\hline Family status & -0.01 & -0.08 & -0.76 & -0.41 \\
\hline Store visits & 0.05 & 0.74 & -0.03 & -0.04 \\
\hline Grocery spending per person & -0.003 & -1.34 & 0.02 & 0.82 \\
\hline PL proneness & -0.43 & $-5.99 * * *$ & -4.46 & $-6.17^{* * *}$ \\
\hline Household care & 0.27 & 0.70 & 0.59 & 0.14 \\
\hline Beverages & 0.29 & 1.04 & 7.47 & $2.62^{* * *}$ \\
\hline Supermarket 1 dummy & 0.80 & 2.37 & -3.80 & -1.13 \\
\hline Supermarket 2 dummy & 0.76 & 2.05 & -8.71 & -2.37 \\
\hline Supermarket 3 dummy & 1.16 & $3.11 *$ & 1.36 & 0.37 \\
\hline $2 \mathrm{LL}$ & 5498.15 & & $10,800.26$ & \\
\hline Parameters & 52 & & 22 & \\
\hline AIC & 5602.15 & & $10,844.27$ & \\
\hline $\mathrm{BIC}$ & 5865.21 & & $10,955.56$ & \\
\hline
\end{tabular}

Note: ${ }^{* * *} p<0.01 ;{ }^{* *} p<0.05 ;{ }^{*} p<0.10$.

consumers, the real brand might represent a continuous, holistic, and reliable process (not a one-off object they purchase) facilitated by the manufacturer to help them to make these items a coherent part of their consumption lifestyle.

The finding holds several implications for managers in circumstances in which the quality gap seems to be losing its edge in influencing willingness to pay. Firstly, managers should consider developing authenticity-enhancing strategies (Beverland, 2009). This includes, among other things, projecting authenticity through developing subtle (unobtrusive) marketing strategies focused on brand history, artisanship, community engagement, and authentic leadership. Secondly, managers should encourage 
Table 6 Hypotheses.

\begin{tabular}{|c|c|c|c|c|}
\hline & $\begin{array}{l}\text { Mediating effect } \\
\text { (between } \\
\text { marketing } \\
\text { factors and } \\
\text { willingness to } \\
\text { pay) }\end{array}$ & $\begin{array}{l}\text { Moderating effect } \\
\text { (perceived } \\
\text { authenticity gap/ } \\
\text { willingness to pay } \\
\text { association) }\end{array}$ & Willingness to pay & $\begin{array}{l}\text { Perceived } \\
\text { authenticity gap }\end{array}$ \\
\hline $\begin{array}{l}\text { Perceived } \\
\text { authenticity gap }\end{array}$ & H1 $\chi^{2}=66.41^{* * *}$ & & $H 2:+\left(\beta=4.71^{* * *}\right)$ & \\
\hline Brand loyalty & & H3b: $-(\beta=-0.50 *)$ & H3a: $+\left(\beta=3.15^{* * *}\right)$ & \\
\hline Advertising & & & & $\mathrm{H} 4:-(\beta=0.12)$ \\
\hline $\begin{array}{l}\text { Product } \\
\text { innovation }\end{array}$ & & & & $H 5:-(\beta=-0.05)$ \\
\hline $\begin{array}{l}\text { Distinctive } \\
\text { packaging }\end{array}$ & & & & $H 6:+\left(\beta=0.42^{* * *}\right)$ \\
\hline Price promotion & & & & $H 7: \pm(\beta=0.16 *)$ \\
\hline PL production & & & & H8a: $-(\beta=-0.09)$ \\
\hline $\begin{array}{l}\text { Difficulty of } \\
\text { production }\end{array}$ & & & & $H 8 b:+\left(\beta=0.11^{* *}\right)$ \\
\hline
\end{tabular}

transcendent evaluation of brands (Podolny \& Hill-Popper, 2004). In this case, the view of a consumer who is deeply immersed in brand appreciation; identifies him/herself via corporate values, identities, myths, and heroes; and appreciates a brand as an art artefact is to be promoted. Last but not least, managers should consider re-routing branding and marketing investments from building object representations to building sincere customermarketer relationships. This would require a degree of moral self-reflexivity based on good faith, honesty, sincerity, and consumer advocacy, which are the essential bedrocks of the authentic brand.

Also, we find that brand loyalty reduces the strength of the perceived authenticity gap's effect on willingness to pay, while having a significantly positive direct effect on willingness to pay. This finding sets a boundary condition: authenticity-enhancing strategies are likely to be effective in the context of reduced brand loyalty or in categories where consumers generally have no brand preference. This insight is especially valuable to managers as industry experts have argued that PLs are generally successful in categories where there is a lack of discernible brand preference (CoriolisResearch, 2002). Hence, managers should consider expanding the authenticity gap in categories where it is difficult to attain or maintain brand loyalty. Another key implication of the finding is that NB managers must become aware of the counter-intuitive role of PLs. Podolny and Hill-Popper (2004) indicate that transcendent valuation is enhanced by other objects that enter into the assessment process as a means of better understanding, but not as objects for comparison. This insight should lead managers to realise that PLs are in fact an integral part of the authenticity perception process: authentic brands could in fact gain rather than lose from PL entry. Furthermore, they should welcome PL entry as an opportunity - and certainly not as a threat - which could be used to enhance sincere relationships with customers. 
The current study shows that not all marketing and production factors influence the authenticity gap. Consumer perceptions of advertising, product innovation, and PL production by NB manufacturers had an insignificant influence on the perceived authenticity gap. This finding more or less supports the expectation that some massmarketing techniques are not suitable for authenticity-enhancing purposes. This differs from Steenkamp et al.'s (2010) study, which demonstrated that the same marketing and manufacturing factors significantly influenced the quality gap. Consequently, Steenkamp et al.'s recommendation to managers was to intensify the use of marketing tools and counter (support) unfavourable (favourable) productionrelated beliefs. However, PLs could employ similar tactics to close the gap. This might create a 'vicious circle' whereby NB and PL manufacturers might find themselves in a dynamic stalemate. In contrast, we believe that the vicious circle could be avoided if managers refocused on authenticity. In contexts in which NB managers give up manipulating brands as objects and instead focus on sincere customer relationships, the use of PLs as 'objects' would widen the authenticity gap.

Distinctive packaging is found to enhance the authenticity gap, while contrary to conventional thinking, managers should realise that under increased authenticity sensitivity the distinctiveness of packaging does not flow from observable physical differences. Rather, the source of the distinctiveness is the fact that other packages (e.g. PLs) imitate the original object (e.g. NB), thereby amplifying the perception of NBs' genuineness and also reinforcing PLs' insincerity. NB packaging becomes a means of stronger, distinct customermarketer alignment. From the authenticity perspective, copycatting should not be viewed as a threat, but again as an opportunity to capitalise on. NB managers must design packaging and communication strategies that reveal better, in subtle ways, inauthentic (i.e. copycatting, counterfeiting, non-genuine) strategies employed by PLs.

The fact that price promotion positively influences the authenticity gap is an interesting finding. In the context of heavy NB promotion in a category, consumers might take frequent price promotions as a sign of a firm's genuine concern for its customers. Authentic brands empower consumers (Beverland \& Farrelly, 2010); hence, by offering better deals authentic brands can reinforce NBs' image of sincerely caring for consumers (rather than profits). Therefore, in marketing communications, managers could consider portraying significant price promotions as 'sacrifices' that authentic companies are prepared to make for consumer welfare. Under the conditions when the authenticity gap mediates willingness to pay, and brand loyalty is insignificant, managers should consider shifting funds from advertising to price promotion as long as they are prepared to help consumers to interpret increased price promotion as care for consumers' general welfare.

We find that the perceived difficulty of producing the product increases the authenticity gap. It is known that authentic products are difficult to manufacture: they require high-quality materials, skilful craftsmanship, excellent workmanship, expertise, professionalism, genuine dedication, and devotion that is time-tested (Beverland, 2009). To increase the authenticity gap and thus improve willingness to pay, managers must focus on the following strategies: focusing on history; portraying founding fathers as heroes who challenged old practices; highlighting the role of employees as real people; and communicating about smart production and process solutions. 


\section{Limitations and future research}

Future research is needed to address several limitations that pertain to the current study. The authenticity gap construct needs further development. It could be based on the recently developed brand authenticity construct (Napoli et al., 2014). While the current study borrows a number of conventional marketing factors proven to drive the quality gap, and tests whether these factors drive the authenticity gap, we are of the opinion that future research should pursue further identification of different marketing factors that uniquely drive the authenticity gap. For instance, future research might look into how guerrilla or covert advertising influences the authenticity gap, as the consumer might not associate these techniques with conventional methods of commercial communication. Moreover, future research could focus on cognitive mechanisms through which consumers activate transcendent versus hedonic valuation, and how these mechanisms influence consumer evaluation of NBs versus PLs. It would be of special interest to examine whether more authentic NBs would really gain, rather than lose, from PL entry.

\section{Disclosure statement}

No potential conflict of interest was reported by the author.

\section{References}

Ailawadi, K. L., Pauwels, K., \& Steenkamp, J. B. E. M. (2008). Private-label use and store loyalty. Journal of Marketing, 72(6), 19-30. doi:10.1509/jmkg.72.6.19

Alexander, N. (2009). Brand authentication: Creating and maintaining brand auras. European Journal of Marketing, 43(3/4), 551-562. doi:10.1108/03090560910935578

Apelbaum, E., Gerstner, E., \& Naik, P. A. (2003). The effects of expert quality evaluations versus brand name on price premiums. Journal of Product \& Brand Management, 12(3), 154-165. doi:10.1108/10610420310476915

Baron, R. M., \& Kenny, D. A. (1986). The moderator-mediator variable distinction in social psychological research: Conceptual, strategic, and statistical considerations. Journal of Personality and Social Psychology, 51(6), 1173-1182. doi:10.1037/0022-3514.51.6.1173

Beverland, M. B. (2005a). Brand management and the challenge of authenticity. Journal of Product \& Brand Management, 14(7), 460-461. doi:10.1108/10610420510633413

Beverland, M. B. (2005b). Crafting brand authenticity: The case of luxury wines. Journal of Management Studies, 42(5), 1003-1029. doi:10.1111/j.1467-6486.2005.00530.x

Beverland, M. B. (2009). Building brand authenticity: Seven habits of iconic brands. Basingstoke: Palgrave Macmillan.

Beverland, M. B., Farrelly, F., \& Quester, P. G. (2010). Authentic subcultural membership: Antecedents and consequences of authenticating acts and authoritative performances. Psychology and Marketing, 27(7), 698-716. doi:10.1002/mar.20352

Beverland, M. B., \& Farrelly, F. J. (2010). The quest for authenticity in consumption: Consumers' purposive choice of authentic cues to shape experienced outcomes. Journal of Consumer Research, 36(5), 838-856. doi:10.1086/615047

Beverland, M. B., Lindgreen, A., \& Vink, M. W. (2008). Projecting authenticity through advertising: Consumer judgments of advertisers' claims. Journal of Advertising, 37(1), 515. doi:10.2753/JOA0091-3367370101 
Beverland, M. B., \& Luxton, S. (2005). Managing integrated marketing communication (IMC) through strategic decoupling: How luxury wine firms retain brand leadership while appearing to be wedded to the past. Journal of Advertising, 34(4), 103-116. doi:10.1080/ 00913367.2005.10639207

Brown, S., \& Sherry Jr., J. F. Eds. (2003) Time, space, and the market: Retroscapes rising. Armonk, NY: M.E. Sharpe.

Brown, S., Sherry Jr., J. F., \& Kozinets, R. V. (2003). Teaching old brands new tricks: Retro branding and the revival of brand meaning. Journal of Marketing, 67(3), 19-33. doi:10.1509/jmkg.67.3.19.18657

Carpenter, G. S., Glazer, R., \& Nakamoto, K. (1994). Meaningful brands from meaningless differentiation: The dependence on irrelevant attributes. Journal of Marketing Research, 31 (3), 339-350. doi:10.2307/3152221

Cohen, E. (1988). Authenticity and commoditization in tourism. Annals of Tourism Research, 15(3), 371-386. doi:10.1016/0160-7383(88)90028-X

Commuri, S. (2009). The impact of counterfeiting on genuine-item consumers' brand relationships. Journal of Marketing, 73(3), 86-98. doi:10.1509/jmkg.73.3.86

Connor, J. M., \& Peterson, E. B. (1992). Market-structure determinants of national brandprivate label price differences of manufactured food products. The Journal of Industrial Economics, 40(2), 157-171. doi:10.2307/2950507

CoriolisResearch. (2002). Responding to private label. Auckland: Tim Morris.

Coupland, J. C. (2005). Invisible brands: An ethnography of households and the brands in their kitchen pantries. Journal of Consumer Research, 32(1), 106-118. doi:10.1086/429604

De Wulf, K., Odekerken-Schröder, G., Goedertier, F., \& Van Ossel, G. (2005). Consumer perceptions of store brands versus national brands. Journal of Consumer Marketing, 22(4), 223-232. doi:10.1108/07363760510605335

Eggers, F., O’Dwyer, M., Kraus, S., Vallaster, C., \& Güldenberg, S. (2013). The impact of brand authenticity on brand trust and SME growth: A CEO perspective. Journal of World Business, 48(3), 340-348. doi:10.1016/j.jwb.2012.07.018

Erdem, T., Swait, J., \& Valenzuela, A. (2006). Brands as signals: A cross-country validation study. Journal of Marketing, 70(1), 34-49. doi:10.1509/jmkg.2006.70.1.34

Euromonitor. (2013). The new face of private label: Global market trends to 2018. London: Euromonitor International.

Fournier, S. (1998). Consumers and their brands: Developing relationship theory in consumer research. Journal of Consumer Research, 24(4), 343-353. doi:10.1086/209515

Garretson, J. A., Fisher, D., \& Burton, S. (2002). Antecedents of private label attitude and national brand promotion attitude: Similarities and differences. Journal of Retailing, 78(2), 91-99. doi:10.1016/S0022-4359(02)00071-4

Gaski, J. F. (2013). To serve man: A marketing manifesto (and an article that should not have been necessary). Journal of Public Policy \& Marketing, 32(1), 6-17. doi:10.1509/ jppm.12.095

Grayson, K., \& Martinec, R. (2004). Consumer perceptions of iconicity and indexicality and their influence on assessments of authentic market offerings. Journal of Consumer Research, 31(2), 296-312. doi:10.1086/422109

Holt, D. B. (2002). Why do brands cause trouble? A dialectical theory of consumer culture and branding. Journal of Consumer Research, 29(1), 70-90. doi:10.1086/339922

Holt, D. B. (2004). How brands become icons: The principles of cultural branding. Boston, MA: Harvard Business Press.

Kadirov, D. (2010). Brand authenticity: Scale development and validation. Paper presented at the ANZMAC, Christchurch.

Kadirov, D., Varey, R. J., \& Wooliscroft, B. (2014). Authenticity: A macromarketing perspective. Journal of Macromarketing, 34(1), 73-79. doi:10.1177/0276146713505774

Kumar, N., \& Steenkamp, J.-B. E. M. (2007). Private label strategy: How to meet the store brand challenge. Boston, MA: Harvard Business Press. 
Levy, S. J. (1959). Symbols for sale. Harvard Business Review, 37(4), 117-124.

Livesey, F., \& Lennon, P. (1978). Factors affecting consumers' choice between manufacturer brands and retailer own labels. European Journal of Marketing, 12(2), 158-170. doi:10.1108/EUM0000000004965

MacCannell, D. (1973). Staged authenticity: Arrangements of social space in tourist settings. American Journal of Sociology, 79(3), 589-603. doi:10.1086/225585

MacCannell, D. (1999). The tourist. A new theory of leisure class. Berkeley, CA: University of California Press.

McCracken, G. (1986). Culture and consumption: A theoretical account of the structure and movement of the cultural meaning of consumer goods. Journal of Consumer Research, 13 (1), 71-84. doi:10.1086/209048

Napoli, J., Dickinson, S. J., Beverland, M. B., \& Farrelly, F. (2014). Measuring consumer-based brand authenticity. Journal of Business Research, 67(6), 1090-1098. doi:10.1016/j. jbusres.2013.06.001

Nielsen, (2014). The state of private label around the world: Where it's growing, where it's not, and what the future holds. New York, NY: The Nielsen Company.

Olsen, K. (2002). Authenticity as a concept in tourism research: The social organization of the experience of authenticity. Tourist Studies, 2(2), 159-182. doi:10.1177/ 146879702761936644

Palmatier, R. W., Scheer, L. K., \& Steenkamp, J.-B. E. M. (2007). Customer loyalty to whom? Managing the benefits and risks of salesperson-owned loyalty. Journal of Marketing Research, 44(2), 185-199. doi:10.1509/jmkr.44.2.185

Peñaloza, L. (2000). The commodification of the American West: Marketers' production of cultural meanings at the trade show. The Journal of Marketing, 64(4), 82-109. doi:10.1509/ jmkg.64.4.82.18073

Podolny, J. M., \& Hill-Popper, M. (2004). Hedonic and transcendent conceptions of value. Industrial \& Corporate Change, 13(1), 91-116. doi:10.1093/icc/13.1.91

Preacher, K. J., \& Hayes, A. F. (2004). SPSS and SAS procedures for estimating indirect effects in simple mediation models. Behavior Research Methods, Instruments, \& Computers, 36(4), 717-731. doi:10.3758/BF03206553

Raudenbush, S. W., \& Bryk, A. S. (2002). Hierarchical linear models: Applications and data analysis methods (Vol. 1). Thousand Oaks, CA: Sage Publications.

Rose, R. L., \& Wood, S. L. (2005). Paradox and the consumption of authenticity through reality television. Journal of Consumer Research, 32(2), 284-296. doi:10.1086/432238

Schultz, H., \& Yang, D. J. (1997). Pour your heart into it: How Starbucks built a company one cup at a time. New York, NY: Hyperion.

Sethuraman, R. (2003). Measuring national brands' equity over store brands. Review of Marketing Science, 1(1), 1-26. doi:10.2202/1546-5616.1000

Sethuraman, R., \& Cole, C. (1997). Why do consumers pay more for national brands than for store brands? (Report). Cambridge, MA: Marketing Science Institute.

Sethuraman, R., \& Cole, C. (1999). Factors influencing the price premiums that consumers pay for national brands over store brands. Journal of Product \& Brand Management, 8(4), 340-351. doi:10.1108/10610429910284319

Skuras, D., \& Vakrou, A. (2002). Consumers' willingness to pay for origin labelled wine: A Greek case study. British Food Journal, 104(11), 898-912. doi:10.1108/ 00070700210454622

Soberman, D. A., \& Parker, P. M. (2004). Private labels: Psychological versioning of typical consumer products. International Journal of Industrial Organization, 22(6), 849-861. doi:10.1016/j.ijindorg.2004.03.004

Soberman, D. A., \& Parker, P. M. (2006). The economics of quality-equivalent store brands. International Journal of Research in Marketing, 23(2), 125-139. doi:10.1016/j. ijresmar.2005.09.008 
Steenkamp, J. B. E. M., Van Heerde, H. J., \& Geyskens, I. (2010). What makes consumers willing to pay a price premium for national brands over private labels? Journal of Marketing Research, 47(6), 1011-1024. doi:10.1509/jmkr.47.6.1011

Thompson, C. J., Rindfleisch, A., \& Arsel, Z. (2006). Emotional branding and the strategic value of the Doppelgänger brand image. Journal of Marketing, 70(1), 50-64. doi:10.1509/ jmkg.2006.70.1.50

Wier, M., \& Calverley, C. (2002). Market potential for organic foods in Europe. British Food Journal, 104(1), 45-62. doi:10.1108/00070700210418749

Woodall, T. (2012). Driven to excess? Linking calling, character and the (mis) behaviour of marketers. Marketing Theory, 12(2), 173-191. doi:10.1177/1470593111418797

Yoo, B., Donthu, N., \& Lee, S. (2000). An examination of selected marketing mix elements and brand equity. Journal of the Academy of Marketing Science, 28(2), 195-211. doi:10.1177/ 0092070300282002

Zhao, X., Lynch Jr., J. G., \& Chen, Q. (2010). Reconsidering Baron and Kenny: Myths and truths about mediation analysis. Journal of Consumer Research, 37(2), 197-206. doi:10.1086/651257

\section{About the author}

Djavlonbek Kadirov is a senior lecturer in the School of Business, the Eastern Institute of Technology, New Zealand. He received a PhD in Marketing from the University of Waikato. His research interests include marketing systems, sustainable marketing, marketing ethics, and (in)authenticity. His research has appeared in journals such as the Journal of Macromarketing, Consumption Markets \& Culture, and Journal of Customer Behaviour.

Djavlonbek Kadirov, Private Bag 1201, HB Mail Centre, Napier 4142, New Zealand.

T 6469748000 ext 5020

Edkadirov@eit.ac.nz 